Characterization of free amino acids, bacteria and fungi in size-segregated atmospheric aerosols in boreal forest: seasonal patterns, abundances and size distributions

Aku Helin ${ }^{1}$, Outi-Maaria Sietiö ${ }^{2}$, Jussi Heinonsalo ${ }^{2}$, Jaana Bäck ${ }^{3}$, Marja-Liisa Riekkola ${ }^{1}$ and Jevgeni Parshintsev ${ }^{1 *}$

${ }^{1}$ Laboratory of Analytical Chemistry, Department of Chemistry, P.O. Box 55, 00014 University of Helsinki, Finland

${ }^{2}$ Division of Microbiology and Biotechnology, Department of Food and Environmental Sciences, University of Helsinki, P.O. Box 56, 00014, Finland

${ }^{3}$ Department of Forest Sciences, University of Helsinki, P.O. Box 27, FI-00014, Finland

Corresponding authors:

*Jevgeni Parshintsev. Tel: +358 503028326. E-mail address: evgeny.parshintsev@helsinki.fi

Summary of number of pages, figures and tables:

Number of Pages: 23

Number of Tables: 6

Number of Figures: 9 


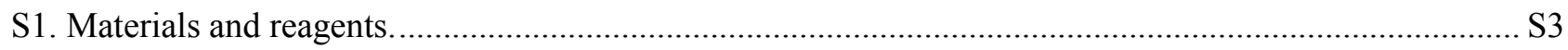

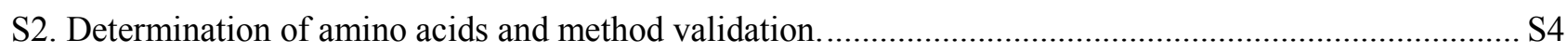

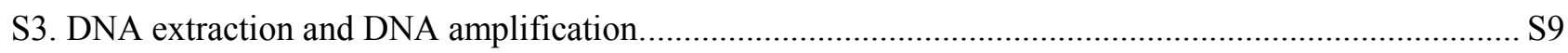

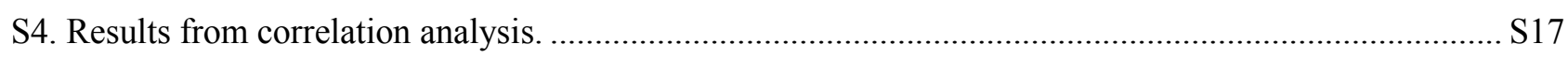

S5. Estimation of biomass contribution to particulate matter in aerosols. ............................................... S2

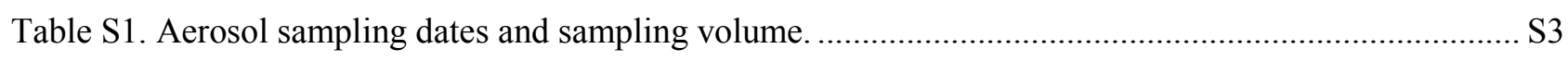

Table S2. Optimized dynamic multiple reaction monitoring (MRM) mode settings for each amino acid. .... S5

Table S3. Information about calibration curve, LOQ and intermediate precision. ....................................... S7

Table S4. Results from different recovery experiments and expanded measurement uncertainty (U). ..........S8

Table S5. Primer pairs used for qPCR assays; primer sequences and approximate amplicon lengths and

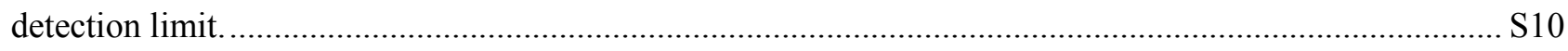

Table S6. Concentration $\left(\mathrm{ng} / \mathrm{m}^{3}\right)$ of each amino acid found in different particle size fractions................... S11

Figure S1. Dynamic multiple reaction monitoring chromatogram of analysis of $240 \mathrm{nmol} / \mathrm{L}$ standard solution

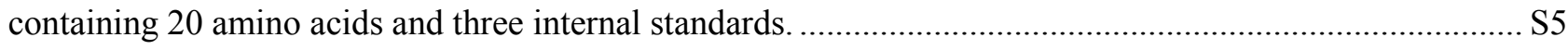

Figure S2. DNA concentration detected over the sampling period in different particle size fractions......... S12

Figure S3. Particulate matter concentration over the sampling period in different particle size fractions.... S13

Figure S4. Relative abundance of a) free amino acids b) bacteria c) Pseudomonas and d) fungi in different

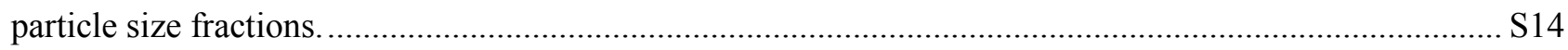

Figure S5. Amino acid relative concentration distribution in each size fraction......................................... S15

Figure S6. Relative amount of bacteria belonging to genus Pseudomonas compared against all the bacteria

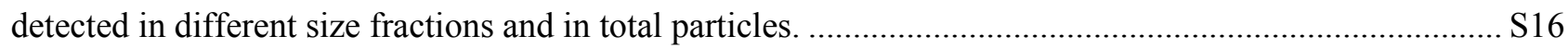

Figure S7. Illustration of correlation diagram presenting Spearman correlations between microorganisms with meteorological variables.

Figure S8. Illustration of correlation diagram presenting Spearman correlations between free amino acids with meteorological variables.

Figure S9. The pattern of Pseudomonas concentration in the size fraction 1-2.5 $\mu \mathrm{m}$ and maximum amount of rainfall recorded on a single 30 min event within $72 \mathrm{~h}$ before sampling. 
S1. Materials and reagents.

L-Tryptophan, L-Phenylalanine, L-Leucine, L-Isoleucine, L-Methionine, L-Tyrosine, L-Valine, L-Proline, LAlanine, L-Threonine, Glycine, L-Glutamic acid, L-Aspartic acid, L-Glutamine and L-Lysine hydrochloride were purchased from Seikagaku Kogyo Co. (Tokyo, Japan). L-Histidine (purity $\geq 99 \%$ ) and L-Arginine (purity 99\%) were purchased from Merck (Darmstadt, Germany). L-Serine (purity ca. 99\%) was purchased from EgaChemie (Steinheim, Germany) and D/L-Cysteine (purity 97\%) was purchased from Aldrich-Chemie (Steinheim, Germany). Asparagine anhydrous (purity $\geq 98 \%$ ) was purchased from Sigma Chemical Co (St. Louis, USA). L-Phenylalanine-3,3- $\mathrm{d}_{2}$ (98 atom \% D), Glycine-2,2- $\mathrm{d}_{2}\left(98\right.$ atom \% D) and L-Lysine-4,4,5,5- $\mathrm{d}_{4}$ hydrochloride (98 atom \% D, 98\% (CP)) were purchased from Aldrich (St. Louis, USA) and these deuterated amino acids were used as internal standards (ISTD). Formic acid (purity 99\%) was purchased from Acros Organics (Geel, Belgium) and acetic acid (purity $\geq 99 \%$ ) was from Fluka Chemie GmbH (Buchs, Switzerland). Toluene (purity 100\%) and $n$-hexane (purity 98\%) were purchased from VWR Chemicals (Fontenay-sousBois, France). Acetonitrile (purity $\geq 99.9 \%$ ) from Sigma-Aldrich (St. Louis, USA) and ultrapure water (Millipore DirectQ-UV, Billerica, MA, USA) were used for the HPLC analysis.

Primary standard solutions of amino acids and ISTDs were prepared separately by weighting and diluting the crystalline compounds in $0.1 \%$ formic acid. The primary solution concentrations were approximately 2000 $\mu \mathrm{mol} / \mathrm{L}-8000 \mu \mathrm{mol} / \mathrm{L}$. A working mixture standard solution containing $80 \mu \mathrm{mol} / \mathrm{L}$ of each amino acid was prepared in $0.1 \%$ formic acid. A working ISTD mixture solution was prepared similarly. Standard solutions at concentrations of 8,40,80,160,240,320 and $400 \mathrm{nmol} / \mathrm{L}$ of each amino acid were prepared by pipetting appropriate amount of working solution and diluting with $0.1 \%$ formic acid. All the standard solutions were containing $100 \mathrm{nmol} / \mathrm{L}$ of each ISTD. Working standard solutions and calibration solutions were prepared each day of analysis. All the solutions were stored in the dark at $4{ }^{\circ} \mathrm{C}$.

Table S1. Aerosol sampling dates and sampling volume. One sampling date was excluded from the data set A due to deviating sampling period length.

\begin{tabular}{|c|c|c|c|c|c|}
\hline \multicolumn{3}{|c|}{ Set A } & \multicolumn{3}{|c|}{ Set B } \\
\hline Start & Stop & $\begin{array}{c}\text { sampling } \\
\text { volume }\left(\mathrm{m}^{3}\right)\end{array}$ & Start & Stop & $\begin{array}{c}\text { sampling } \\
\text { volume }\left(\mathrm{m}^{3}\right)\end{array}$ \\
\hline 31.1.2014 9:30 & $3.2 .20148: 40$ & 133 & 3.2.2014 8:40 & 5.2.2014 9:04 & 92 \\
\hline 21.2.2014 9:04 & 24.2.2014 9:44 & 124 & 25.2.2014 9:00 & 28.2.2014 10:10 & 121 \\
\hline 7.3.2014 8:47 & $10.3 .20148: 43$ & 119 & $10.3 .20148: 43$ & 12.3.2014 8:45 & 80 \\
\hline 21.3.2014 9:02 & 24.3.2014 9:20 & 132 & 24.3.2014 9:20 & 26.3.2014 8:25 & 86 \\
\hline 4.4.2014 8:02 & 7.4.2014 7:58 & 133 & 7.4.2014 7:58 & 9.4.2014 7:39 & 92 \\
\hline $16.4 .20147: 44$ & $23.4 .20148: 15$ & 300 & 23.4.2014 8:15 & 25.4.2014 7:35 & 84 \\
\hline 7.5.2014 7:40 & 9.5 .2014 7:54 & 80 & 9.5 .2014 7:54 & 12.5 .2014 7:50 & 125 \\
\hline 21.5.2014 7:39 & 22.5 .2014 7:30 & 93 & $22.5 .20147: 30$ & 26.5.2014 9:12 & 144 \\
\hline 4.6.2014 7:50 & 6.6.2014 8:03 & 93 & 6.6.2014 8:03 & 9.6.2014 7:46 & 138 \\
\hline 25.6.2014 7:33 & 27.6.2014 7:47 & 79 & 27.6.2014 7:47 & 30.6.2014 8:13 & 118 \\
\hline 9.7.2014 7:41 & 11.7.2014 7:58 & 89 & 11.7.2014 7:58 & 14.7.2014 6:48 & 128 \\
\hline 30.7.2014 7:00 & $1.8 .20146: 56$ & 96 & $1.8 .20146: 56$ & 4.8.2014 7:09 & 142 \\
\hline $8.8 .20146: 58$ & 11.8.2014 7:04 & 141 & 11.8.2014 7:04 & $13.8 .20146: 55$ & 92 \\
\hline 22.8.2014 7:00 & 25.8.2014 7:04 & 122 & 25.8.2014 7:04 & 27.8.2014 7:04 & 83 \\
\hline 8.9.2014 7:58 & 10.9.2014 8:00 & 82 & 10.9.2014 8:00 & 12.9.2014 8:15 & 84 \\
\hline 19.9.2014 7:59 & 22.9.2014 8:05 & 119 & 22.9.2014 8:05 & 24.9.2014 8:25 & 76 \\
\hline 29.9.2014 7:58 & 1.10.2014 8:01 & 81 & 1.10 .2014 8:01 & 3.10 .2014 7:10 & 83 \\
\hline 24.10.2014 8:35 & 27.10.2014 9:27 & 114 & $27.10 .20149: 27$ & 29.10.2014 9:02 & 79 \\
\hline
\end{tabular}


S2. Determination of amino acids and method validation.

Aerosol sample extraction

Ultrasonic assisted extraction with $0.1 \%$ formic acid as solvent was used for the extraction of free amino acids from the collection substrates. All the tools used in the following process were cleaned with water and methanol under sonication and dried in an oven at $150^{\circ} \mathrm{C}$. Filter was removed from the petri dish with tweezers and placed into a test tube. Due to the grease used to cover the filters, there was a spot of grease left onto the surface of the petri dish. In order to recover all the particles, the grease spot was dissolved with hexane and the solute was pipetted into the test tube. Filter was spiked with $100 \mu \mathrm{L}$ of isotopically labelled amino acid internal standard mixture solution. The sample was sonicated at room temperature for 15 minutes with $2 \mathrm{~mL}$ of $0.1 \%$ formic acid. Sonication was repeated twice with $2 \mathrm{~mL}$ and $1 \mathrm{~mL}$ of $0.1 \%$ formic acid for 10 minutes each time. Finally, $1 \mathrm{~mL}$ of toluene was added into the extract solution in order to ensure partitioning of the grease into organic phase. The solution was vortexed and centrifuged. Aqueous layer was separated and filtered through a $0.45 \mu \mathrm{m}$ filter (Merck Millipore Ltd., Tullagreen, Ireland) into a $5 \mathrm{~mL}$ volumetric flask. The samples were stored at $4{ }^{\circ} \mathrm{C}$ and analyzed within 72 hours. Blank filters were processed simultaneously with the real samples and used for blank correction.

Chromatographic analysis

The analyses were performed with an Agilent 1260 Infinity HPLC coupled to an Agilent 6420 triple quadrupole mass spectrometer (Agilent Technologies, USA). Electrospray ionization in positive mode was used. The column used was a SeQuant ZIC-cHILIC (100 x $2.1 \mathrm{~mm}$, particle size $3 \mu \mathrm{m}, 100 \AA$, Merck KGaA, Germany). The column temperature was maintained at $30{ }^{\circ} \mathrm{C}$ and the injection volume was $3 \mu \mathrm{L}$. Eluent $\mathrm{A}$ was $0.01 \%$ acetic acid in acetonitrile and eluent $\mathrm{B}$ was $0.01 \%$ acetic acid in ultrapure water. The optimized gradient program was as follows: $0-10 \mathrm{~min}, 20 \%$ eluent $\mathrm{B} ; 10-20 \mathrm{~min}, 60 \%$ eluent $\mathrm{B} ; 20-40 \mathrm{~min}, 60 \%$ eluent B; 40-45 min, 20\% eluent B and equilibration for $25 \mathrm{~min}$. All the mobile phase gradient changes were linear and the flow rate was $150 \mu \mathrm{L} / \mathrm{min}$. Mass spectrometer (MS) source parameters were optimized and they were set as follows: drying gas temperature $350{ }^{\circ} \mathrm{C}$, drying gas flow rate $12 \mathrm{~L} / \mathrm{min}$, nebulizer pressure $40 \mathrm{psi}$ and capillary voltage $+4000 \mathrm{~V}$. The MS was operated in a dynamic multiple reaction monitoring (MRM) mode. Precursor ions and product ions were selected based on observations during method development. Fragmentor voltage, collision energy and cell accelerator voltage were optimized for each amino acid separately (Table S2). An example chromatogram of the analysis of amino acid standard solution is shown in Figure S1. 
Table S2. Optimized dynamic multiple reaction monitoring (MRM) mode settings for each amino acid.

\begin{tabular}{cccccc}
\hline Amino acid & $\begin{array}{c}\text { Precursor } \\
\text { ion }\end{array}$ & $\begin{array}{c}\text { Product } \\
\text { ion }\end{array}$ & $\begin{array}{c}\text { Fragmentor } \\
\text { voltage (V) }\end{array}$ & $\begin{array}{c}\text { Collision } \\
\text { energy (V) }\end{array}$ & $\begin{array}{c}\text { Cell } \\
\text { Accelerator } \\
\text { Voltage (V) }\end{array}$ \\
\hline Alanine (Ala) & 90 & 44 & 70 & 10 & 3 \\
Arginine (Arg) & 175 & 70 & 80 & 15 & 3 \\
Asparagine (Asn) & 133 & 87 & 70 & 5 & 3 \\
Aspartic acid (Asp) & 134 & 74 & 75 & 15 & 3 \\
Cysteine (Cys) & 122 & 76 & 70 & 15 & 3 \\
Glutamine (Gln) & 147 & 130 & 70 & 5 & 3 \\
Glutamic acid (Glu) & 148 & 130 & 70 & 5 & 3 \\
Glycine (Gly) & 76 & 30 & 70 & 5 & 3 \\
Glycine-d $($ Gly-d 2 ) & 78 & 32 & 70 & 10 & 3 \\
Histidine (His) & 156 & 110 & 80 & 15 & 3 \\
Isoleucine+Leucine (Ile+Leu) & 132 & 86 & 75 & 10 & 3 \\
Lysine (Lys) & 147 & 130 & 70 & 5 & 3 \\
Lysine-d $\left(\right.$ Lys- $\mathrm{d}_{4}$ ) & 151 & 134 & 70 & 5 & 3 \\
Methionine (Met) & 150 & 133 & 70 & 5 & 3 \\
Phenylalanine (Phe) & 166 & 120 & 80 & 10 & 3 \\
Phenylalanine-d (Phe-d $_{2}$ ) & 168 & 122 & 80 & 10 & 3 \\
Proline (Pro) & 116 & 70 & 80 & 15 & 3 \\
Serine (Ser) & 106 & 60 & 70 & 10 & 3 \\
Threonine (Thr) & 120 & 74 & 75 & 10 & 3 \\
Tryptophan (Trp) & 205 & 188 & 80 & 5 & 3 \\
Tyrosine (Tyr) & 182 & 136 & 75 & 10 & 3 \\
Valine (Val) & 118 & 72 & 75 & 10 & 3 \\
\hline
\end{tabular}

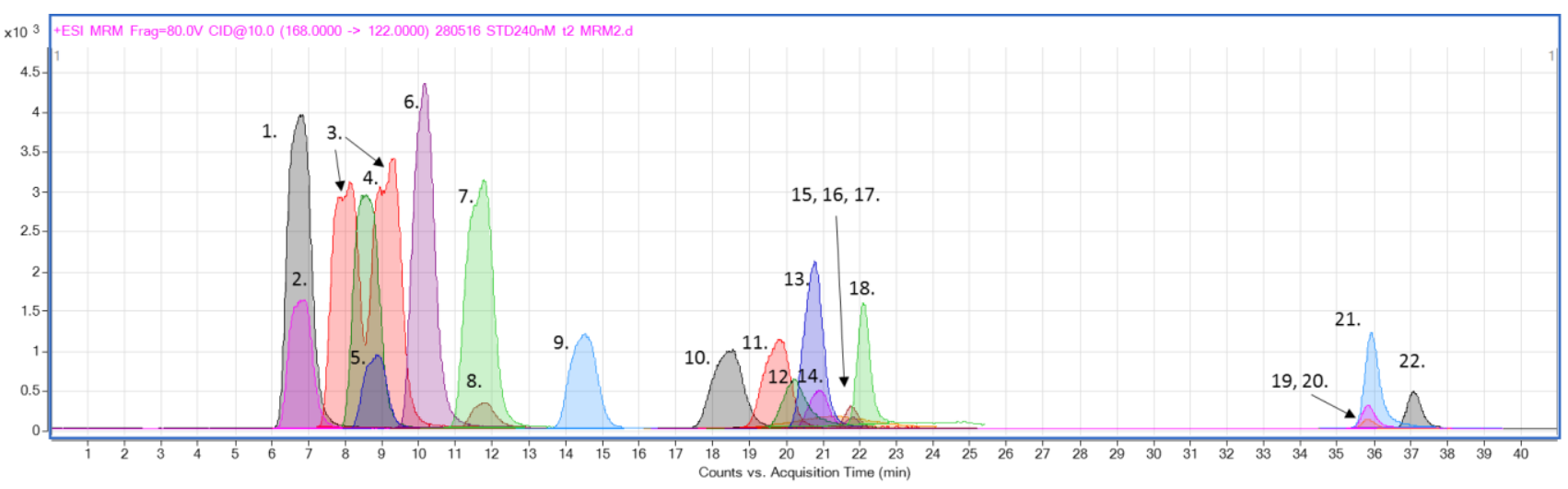

Figure S1. Dynamic multiple reaction monitoring chromatogram of analysis of $240 \mathrm{nmol} / \mathrm{L}$ standard solution containing 20 amino acids and three internal standards. Peak identification: 1. Phe, 2. Phe- $\mathrm{d}_{2}, 3$. Ile+Leu, 4. Trp, 5. Met, 6. Pro, 7. Val, 8. Cys, 9. Tyr, 10. Thr, 11. Ala, 12. Glu, 13. Gln, 14.Asn, 15. Asp, 16. Gly, 17. Gly-d $\mathrm{d}_{2}, 18$. Ser, 19. Lys, 20. Lys- $\mathrm{d}_{4}, 21$. His and 22. Arg. 
Validation experiments and quality control

The amino acid concentrations were quantified by using internal standard method with three isotopically labelled amino acids. Prior to analysis of aerosol samples, linear calibration curves were prepared each time by analyzing standard solutions $(8-400 \mathrm{nmol} / \mathrm{L}$, two repetitions per standard). On average, six aerosol samples were analyzed by using a single calibration curve. This was done in order to minimize day-to-day signal variation. Most of the amino acid calibration curves were forced through origin, except for glycine and histidine the lowest point used was the LOQ value. There were few aerosol samples that had relatively high concentration levels of amino acids present, exceeding the normal calibration range. In order to quantify the amino acid concentrations in these samples, $700-50000 \mathrm{nmol} / \mathrm{L}$ standard solutions were analyzed and quadratic fit was applied.

The limit of quantification (LOQ) for the entire analytical procedure was determined by processing and analyzing multiple field blank filters $(n=14)$. Equation $L O Q=A+10 * S D$, where $A=$ average peak area and $\mathrm{SD}=$ standard deviation, was used for the calculations of LOQ values. Some of the amino acids were absent in the blank samples and thus the LOQ was estimated by using signal-to-noise ratio of ten.

Different types of recovery experiments were done in order to: i) determine extraction recovery and ii) examine matrix effects. First, extraction recovery was determined by spiking four blank filters with $100 \mu \mathrm{L}$ of 10 $\mu \mathrm{mol} / \mathrm{L}$ amino acid mixture solution ( $\mathrm{c}=200 \mathrm{nmol} / \mathrm{L}$ in solution) and the filters were processed in the same manner as real samples. These spiked blank filter recovery experiments were done in order to determine the recovery of amino acids from the filters, i.e. to test the extraction efficiency. The second type of recovery experiments were done with real samples, that were already extracted and analyzed. In these experiments, 195 $\mu \mathrm{L}$ of real sample was pipetted into a $\mathrm{LC}$ vial and $5 \mu \mathrm{L}$ of amino acid mixture solution was added into the solution. These experiments were done with two different spiking concentrations $(\mathrm{c}=50 \mathrm{nmol} / \mathrm{L}$ and $\mathrm{c}=100$ $\mathrm{nmol} / \mathrm{L}$ in solution) and with four samples per concentration level. These recovery experiments, i.e. matrix matched recovery experiments, were done in order to simulate possible matrix effects.

The expanded measurement uncertainty (U) was estimated applying single laboratory validation Nordtestapproach. ${ }^{1}$ The intermediate precision and recovery experiment results were used in the calculation of $U$ by using the $95 \%$ confidence limit.

\section{Validation results}

All the relevant calibration curve information, such as calibration range, $\mathrm{R}^{2}$ and ISTD for each amino acid, is shown in Table S3. The correlation coefficients of the linear calibration curves were generally above 0.9983 . Linearity was evaluated based on residual analysis. Calibration curve slope stabilities were in the range 2.5$27.8 \%$ over a one month time period (10 separate calibration curves). In addition, the retention time variation was below 5\% with all of the amino acids during a one month time period. Overall, the method stability was acceptable and the short analysis sequences ensured that the method performance was maintained accurate.

The LOQ for each amino acid and the intermediate precision close to the LOQ values are listed in Table S3. The LOQs varied between $4-160 \mathrm{nmol} / \mathrm{L}$, corresponding to $0.03-1.18 \mathrm{ng} / \mathrm{m}^{3}$ in atmospheric aerosol samples (estimated based on average sampling volume of $105 \mathrm{~m}^{3}$ ). The intermediate precision was calculated from one month time period (22 repetitions per standard) and it is expressed as relative standard deviation. With most of the compounds, the intermediate precision was below $18 \%$, but with tryptophan the intermediate precision was throughout the calibration range approximately $25 \%$.

The different recovery experiments results are shown in Table S4. Some values are left blank because they were below the LOQ. The recovery from the spiked blank filters was around $100 \pm 20 \%$. In the matrix spiking experiments, signal enhancement was observed with some of the compounds. The recovery was in the range of $88-120 \%$, which was still considered to be acceptable. Based on both recovery experiments, it can be concluded that the extraction efficiency was sufficient and the matrix effects were not significantly affecting the results. The expanded measurement uncertainty (U) with $95 \%$ confidence limit is shown in the far most right column of Table S4. The U varied between 31-58\%, which was considered to be fit-for-purpose. 
Table S3. Information about calibration curve, LOQ and intermediate precision.

\begin{tabular}{|c|c|c|c|c|c|c|c|}
\hline $\begin{array}{c}\text { Amino } \\
\text { acid }\end{array}$ & $\begin{array}{c}\text { Internal } \\
\text { standard }\end{array}$ & $\begin{array}{c}\text { Calibration } \\
\text { curve } \\
\text { slope }\end{array}$ & $\begin{array}{c}\text { Slope } \\
\text { stability } \\
\text { (RSD\%) }\end{array}$ & $\begin{array}{c}\text { Calibration } \\
\text { curve } \\
\text { range } \\
\text { (nmol/L) }\end{array}$ & $\mathrm{R}^{2}$ & $\begin{array}{c}\text { LOQ } \\
\text { (nmol/L) })\end{array}$ & $\begin{array}{c}\text { Intermediate } \\
\text { precision }^{\mathrm{b}} \\
\text { (RSD\%) }\end{array}$ \\
\hline Ala & Gly-d2 & 0.044 & 2.5 & $40-400$ & 0.9998 & 20 & 16.2 \\
Arg & Lys-d4 & 0.018 & 5.0 & $40-400$ & 0.9983 & 30 & 9.3 \\
Asn & Gly-d2 & 0.018 & 6.2 & $8-400$ & 0.9998 & 8 & 11.6 \\
Asp & Gly-d2 & 0.013 & 23.0 & $40-400$ & 1.0000 & 20 & 17.4 \\
Cys & Gly-d2 & 0.010 & 8.0 & $40-400$ & 0.9991 & 20 & 17.9 \\
Gln & Gly-d2 & 0.058 & 12.2 & $8-400$ & 0.9993 & 5 & 15.5 \\
Glu & Gly-d2 & 0.023 & 6.7 & $8-400$ & 0.9998 & 8 & 11.5 \\
Gly & Gly-d2 & 0.008 & 5.8 & $40-400$ & 0.9999 & 40 & 10.2 \\
His & Lys-d4 & 0.046 & 8.7 & $160-400$ & 0.9999 & 160 & 11.3 \\
Ile+Leu & Phe-d2 & 0.010 & 5.8 & $16-800$ & 1.0000 & 10 & 7.3 \\
Lys & Lys-d4 & 0.011 & 4.7 & $160-400$ & 0.9998 & 130 & 12.5 \\
Met & Phe-d2 & 0.002 & 4.8 & $8-400$ & 0.9999 & 8 & 7.8 \\
Phe & Phe-d2 & 0.010 & 1.7 & $8-400$ & 1.0000 & 4 & 2.6 \\
Pro & Phe-d2 & 0.009 & 3.7 & $8-400$ & 0.9999 & 5 & 7.2 \\
Ser & Gly-d2 & 0.035 & 6.2 & $80-400$ & 1.0000 & 70 & 10.2 \\
Thr & Gly-d2 & 0.040 & 5.8 & $40-400$ & 0.9993 & 13 & 11.3 \\
Trp & Phe-d2 & 0.004 & 27.8 & $8-400$ & 0.9998 & 8 & 25.3 \\
Tyr & Phe-d2 & 0.003 & 9.7 & $8-400$ & 1.0000 & 7 & 9.1 \\
Val & Phe-d2 & 0.009 & 5.2 & $8-400$ & 1.0000 & 7 & 9.7 \\
\hline
\end{tabular}

${ }^{a}$ One month time period, 10 separate calibration curves

${ }^{\mathrm{b}}$ One month time period, 22 repetitions per standard 
Table S4. Results from different recovery experiments and expanded measurement uncertainty (U).

\begin{tabular}{|c|c|c|c|c|}
\hline & $\begin{array}{c}50 \mathrm{nM} \text { spiked } \\
\text { sample }^{\mathrm{a}}\end{array}$ & $\begin{array}{c}100 \text { nM spiked } \\
\text { sample }^{\mathrm{b}}\end{array}$ & $\begin{array}{l}200 \text { nM spiked } \\
\text { blank }^{\mathrm{c}}\end{array}$ & \\
\hline Amino acid & $\mathrm{RR} \%( \pm \mathrm{sd})$ & $\mathrm{RR} \%( \pm \mathrm{sd})$ & $\mathrm{RR} \%( \pm \mathrm{sd})$ & $\mathrm{U}(\%)$ \\
\hline Ala & $114 \pm 13$ & $114 \pm 2$ & $101 \pm 6$ & 39 \\
\hline Arg & $88 \pm 5$ & $103 \pm 10$ & $97 \pm 2$ & 33 \\
\hline Asn & $108 \pm 8$ & $112 \pm 5$ & $100 \pm 3$ & 30 \\
\hline Asp & $113 \pm 18$ & $108 \pm 12$ & $103 \pm 12$ & 54 \\
\hline Cys & $91 \pm 11$ & $100 \pm 6$ & $94 \pm 3$ & 41 \\
\hline Gln & $89 \pm 9$ & $101 \pm 17$ & $93 \pm 5$ & 42 \\
\hline Glu & $104 \pm 8$ & $111 \pm 15$ & $96 \pm 3$ & 26 \\
\hline Gly & $122 \pm 18$ & $116 \pm 7$ & $105 \pm 9$ & 58 \\
\hline His & - & - & $102 \pm 2$ & 38 \\
\hline Ile+Leu & $116 \pm 7$ & $110 \pm 7$ & $100 \pm 2$ & 37 \\
\hline Lys & - & $103 \pm 6$ & $99 \pm 4$ & 30 \\
\hline Met & $119 \pm 8$ & $115 \pm 7$ & $97 \pm 1$ & 43 \\
\hline Phe & $115 \pm 8$ & $112 \pm 4$ & $99 \pm 2$ & 34 \\
\hline Pro & $112 \pm 11$ & $113 \pm 7$ & $98 \pm 4$ & 35 \\
\hline Ser & - & $120 \pm 10$ & $109 \pm 18$ & 48 \\
\hline Thr & $115 \pm 10$ & $116 \pm 5$ & $96 \pm 4$ & 40 \\
\hline $\operatorname{Trp}$ & $110 \pm 8$ & $99 \pm 6$ & $82 \pm 8$ & 56 \\
\hline Tyr & $110 \pm 10$ & $108 \pm 9$ & $97 \pm 3$ & 33 \\
\hline Val & $112 \pm 8$ & $111 \pm 8$ & $100 \pm 3$ & 31 \\
\hline
\end{tabular}

${ }^{\text {a }} 195 \mu \mathrm{L}$ sample $+5 \mu \mathrm{L} 2000 \mathrm{nmol} / \mathrm{L}$ standard solution $(N=4)$

b $195 \mu \mathrm{L}$ sample $+5 \mu \mathrm{L} 4000 \mathrm{nmol} / \mathrm{L}$ standard solution $(N=4)$

c blank filter spiked $(N=4)$ 
S3. DNA extraction and DNA amplification.

The total nucleic acids extraction with PowerWater DNA Isolation Kit (MoBio Laboratories, USA) was performed according to the manufacturer's instructions with the following modifications. The aerosol filters were inserted into the $5 \mathrm{~mL}$ PowerWater Bead tube and $1 \mathrm{~mL}$ of lysis buffer was added. The samples were incubated in the lysis buffer at $65^{\circ} \mathrm{C}$ for $1 \mathrm{~h}$ and then homogenized with horizontal vortexing for $5 \mathrm{~min}$ at maximum speed. The remaining steps were carried out according to the supplier's protocol, and the DNA was eluted into $100 \mu \mathrm{L}$ of elution buffer.

Blank filters $(\mathrm{n}=6)$ were processed and no contamination was observed in $\mathrm{qPCR}$. DNA concentrations were below $0.282 \mathrm{ng} / \mu \mathrm{L}$ corresponding to $0.003 \mathrm{ng} / \mathrm{m}^{3}$ in atmospheric aerosol samples (estimated based on average sampling volume of $105 \mathrm{~m}^{3}$ ).

The qPCR reactions were carried out with Bio-Rad CFX96 iCycler on 96-well white polypropylene plates (Bio-Rad, USA). The qPCR reaction mixtures were done according to manufacturer's instructions. The bacterial and Pseudomonas genus specific reaction mixtures contained SsoAdvanced universal SYBR Green supermix (Bio-Rad, USA) at final concentration of $1 \mathrm{x}, 5 \mu \mathrm{L}$ of template DNA, $250 \mathrm{nM}$ of forward and reverse primers (Table S5). The reaction volume was adjusted to $20 \mu \mathrm{L}$ with nuclease-free water. With fungal primers, the reaction mixture was otherwise the same, but the FF390 primer was in concentration of $250 \mathrm{nM}$ and the FR1 primer in $200 \mathrm{nM}$. The qPCR reactions were conducted according to the manufacturer's protocol with combined annealing and extension (Table S5). For quantification, fluorescence was measured during the elongation step. From each DNA sample and standard, the three technical replicates were prepared, and from each mastermix three negative controls were analysed. The qPCR products were analysed in $1.5 \%(\mathrm{w} / \mathrm{v})$ agarose gel (BioTop) and visualized with $0.3 \%$ (w/v) ethidium bromide (Sigma-Aldrich) under UV-light to ensure the correct amplicon length and the specificity of amplification (Table S5). Detection limits of the used qPCR method were calculated from the standard curves separately for each primer pair (Table S5). The genus Pseudomonas specific primers produced nonspecific amplicons when the amount of Pseudomonas DNA in the reaction was under detection limit (Table S5). These data points were set as below "detection limit" in Pseudomonas qPCR-results. 
Table S5. Primer pairs used for qPCR assays; primer sequences and approximate amplicon lengths and detection limit.

\begin{tabular}{|c|c|c|c|c|c|c|c|}
\hline Target group & Primer name & Sequence $\left(5^{\prime}->3^{\prime}\right)$ & $\begin{array}{l}\text { Approximate } \\
\text { amplicon } \\
\text { length (bp) }\end{array}$ & $\begin{array}{l}\text { Combined } \\
\text { annealing } \\
\text { and } \\
\text { extension } \\
\text { conditions }\end{array}$ & $\begin{array}{l}\text { Amplification } \\
\text { efficiency }(\%)\end{array}$ & $\begin{array}{c}\text { Detection } \\
\text { limit (cells of } \\
\text { microorganism) }\end{array}$ & Reference \\
\hline \multirow{2}{*}{ All Bacteria } & Eub338f & ACT CCT ACG GGA GGC AGC AG & \multirow{2}{*}{200} & \multirow{2}{*}{$\begin{array}{c}\text { temp } 55^{\circ} \mathrm{C} \\
\text { time } 30 \mathrm{~s}\end{array}$} & \multirow{2}{*}{$96 \%$} & \multirow{2}{*}{$\begin{array}{c}20 \\
\left(0.13 \text { cells } / \mathrm{m}^{3}\right)\end{array}$} & \multirow{2}{*}{$\begin{array}{c}\text { Fierer et al. } \\
2005^{2}\end{array}$} \\
\hline & Eub518r & ATT ACC GCG GCT GCT GG & & & & & \\
\hline \multirow{2}{*}{$\begin{array}{c}\text { Genus: } \\
\text { Pseudomonas }\end{array}$} & Eub338f & ACT CCT ACG GGA GGC AGC AG & \multirow{2}{*}{150} & \multirow{2}{*}{$\begin{array}{c}\text { temp } 55^{\circ} \mathrm{C} \\
\text { time } 30 \mathrm{~s}\end{array}$} & \multirow{2}{*}{$97 \%$} & \multirow{2}{*}{$\begin{array}{c}16 \\
\left(0.15 \text { cells } / \mathrm{m}^{3}\right)\end{array}$} & $\begin{array}{c}\text { Fierer et al. } \\
2005^{2}\end{array}$ \\
\hline & PseudoR & TCG GTA ACG TCA AAA CAG CAA AGT & & & & & $\begin{array}{c}\text { Purohit et al. } \\
2003^{3} \\
\end{array}$ \\
\hline \multirow{2}{*}{ All Fungi } & FF390 & CGA TAA CGA ACG AGA CCT & \multirow{2}{*}{350} & \multirow{2}{*}{$\begin{array}{c}\text { temp } 60{ }^{\circ} \mathrm{C} \\
\text { time } 45 \mathrm{~s}\end{array}$} & \multirow{2}{*}{$89 \%$} & \multirow{2}{*}{$\begin{array}{c}6 \\
\left(0.06 \text { cells } / \mathrm{m}^{3}\right)\end{array}$} & \multirow{2}{*}{$\begin{array}{c}\text { Vainio et al. } \\
2000^{4}\end{array}$} \\
\hline & FR1 & AIC CAT TCA ATC GGT AIT & & & & & \\
\hline
\end{tabular}


Table S6. Concentration $\left(\mathrm{ng} / \mathrm{m}^{3}\right)$ of each amino acid found in different particle size fractions. Average concentration ( \pm standard deviation), detected range and detection frequency (d.f.) percentage are reported.

\begin{tabular}{|c|c|c|c|c|c|c|c|c|c|c|c|c|}
\hline \multirow[b]{2}{*}{ Amino acid } & \multicolumn{3}{|c|}{$<1 \mu \mathrm{m}$} & \multicolumn{3}{|c|}{$1-2.5 \mu \mathrm{m}$} & \multicolumn{3}{|c|}{$2.5-10 \mu \mathrm{m}$} & \multicolumn{3}{|c|}{$>10 \mu \mathrm{m}$} \\
\hline & Average \pm sd & Range & d.f. (\%) & Average \pm sd & Range & d.f. $(\%)$ & Average \pm sd & Range & d.f. $(\%)$ & Average \pm sd & Range & d.f. $(\%)$ \\
\hline Arg & $3.18 \pm 5.76$ & $0.19-11.82$ & 24 & $4.95 \pm 12.94$ & $0.39-39.44$ & 56 & $7.51 \pm 20.44$ & $0.29-69.09$ & 61 & $9.32 \pm 26.94$ & $0.34-101.77$ & 78 \\
\hline Asp & $0.58 \pm 0.82$ & $0.18-2.99$ & 65 & $1.06 \pm 2.12$ & $0.15-6.31$ & 50 & $1.62 \pm 3.53$ & $0.17-12.17$ & 61 & $2.80 \pm 6.66$ & $0.16-19.23$ & 44 \\
\hline Cys & - & - & - & 0.1 & - & 6 & 0.21 & - & 6 & 0.39 & - & 6 \\
\hline Gln & $0.48 \pm 0.54$ & $0.09-2.02$ & 65 & $1.62 \pm 2.04$ & $0.07-7.41$ & 81 & $2.31 \pm 3.39$ & $0.05-13.77$ & 94 & $1.93 \pm 4.55$ & $0.07-19.36$ & 94 \\
\hline His & - & - & - & 1.23 & - & 6 & 2.1 & - & 6 & $2.94 \pm 0.85$ & $2.34-3.54$ & 11 \\
\hline Ile+Leu & $0.39 \pm 0.44$ & $0.09-0.70$ & 12 & $0.90 \pm 1.37$ & $0.07-2.48$ & 19 & $0.72 \pm 1.35$ & $0.08-4.51$ & 56 & $1.01 \pm 2.23$ & $0.08-7.46$ & 61 \\
\hline Lys & 0.95 & - & 6 & 3.59 & - & 6 & 6.27 & - & 6 & 9.27 & - & 6 \\
\hline Met & 0.05 & - & 6 & 0.35 & - & 6 & 0.67 & - & 6 & $0.68 \pm 0.54$ & $0.30-1.07$ & 11 \\
\hline Phe & $0.11 \pm 0.09$ & $0.05-0.18$ & 12 & $0.25 \pm 0.38$ & $0.03-0.82$ & 25 & $0.28 \pm 0.45$ & $0.04-1.53$ & 56 & $0.36 \pm 0.73$ & $0.03-2.35$ & 56 \\
\hline Tyr & $0.14 \pm 0.09$ & $0.08-0.20$ & 12 & $0.43 \pm 0.48$ & $0.09-0.77$ & 13 & $0.36 \pm 0.48$ & $0.06-1.41$ & 39 & $0.51 \pm 0.82$ & $0.05-2.15$ & 33 \\
\hline Val & $0.23 \pm 0.25$ & $0.05-0.41$ & 12 & $0.46 \pm 0.65$ & $0.04-1.20$ & 19 & $0.36 \pm 0.65$ & $0.05-2.26$ & 61 & $0.50 \pm 1.05$ & $0.04-3.51$ & 61 \\
\hline
\end{tabular}




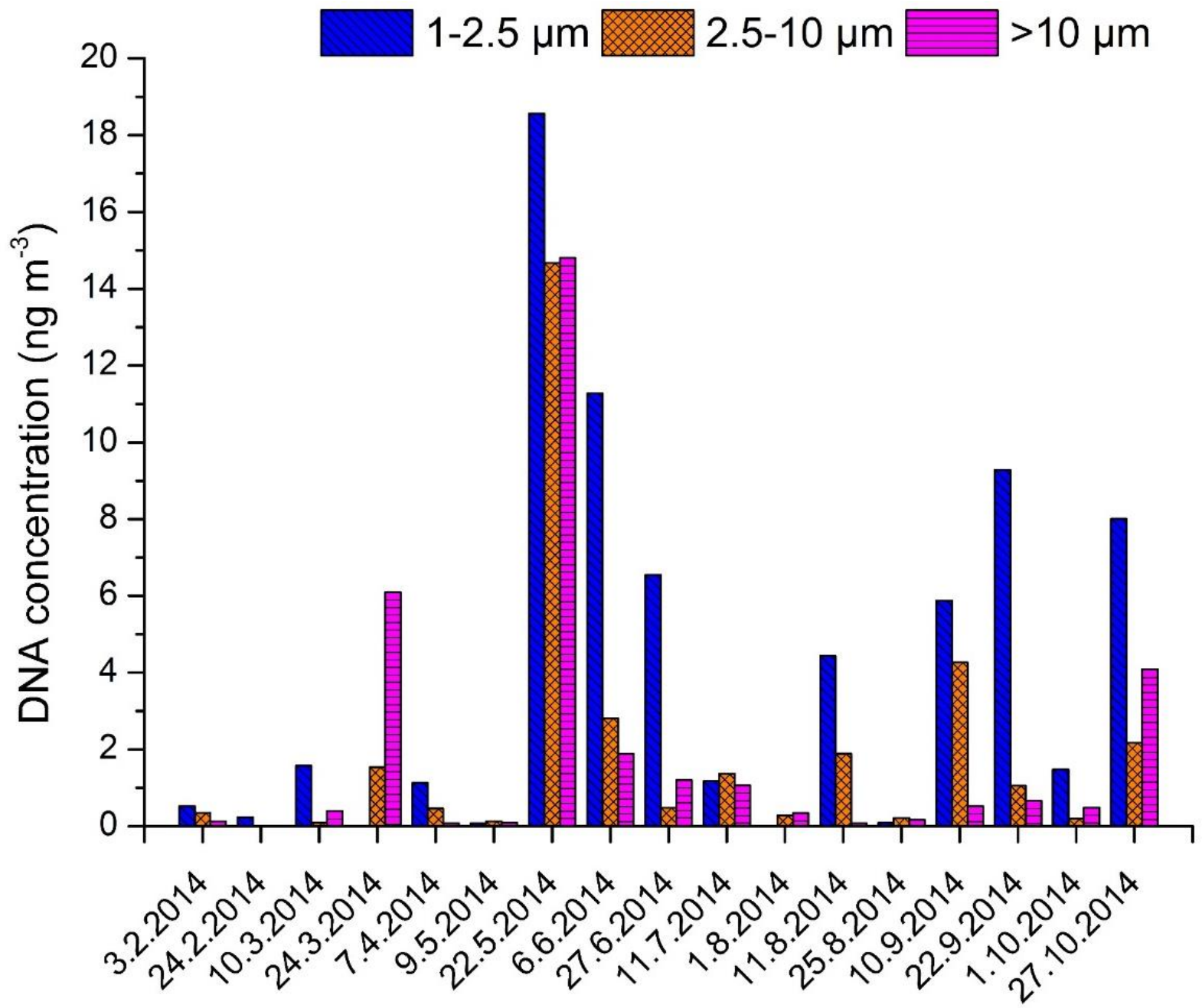

Sampling date

Figure S2. DNA concentration detected over the sampling period in different particle size fractions. 


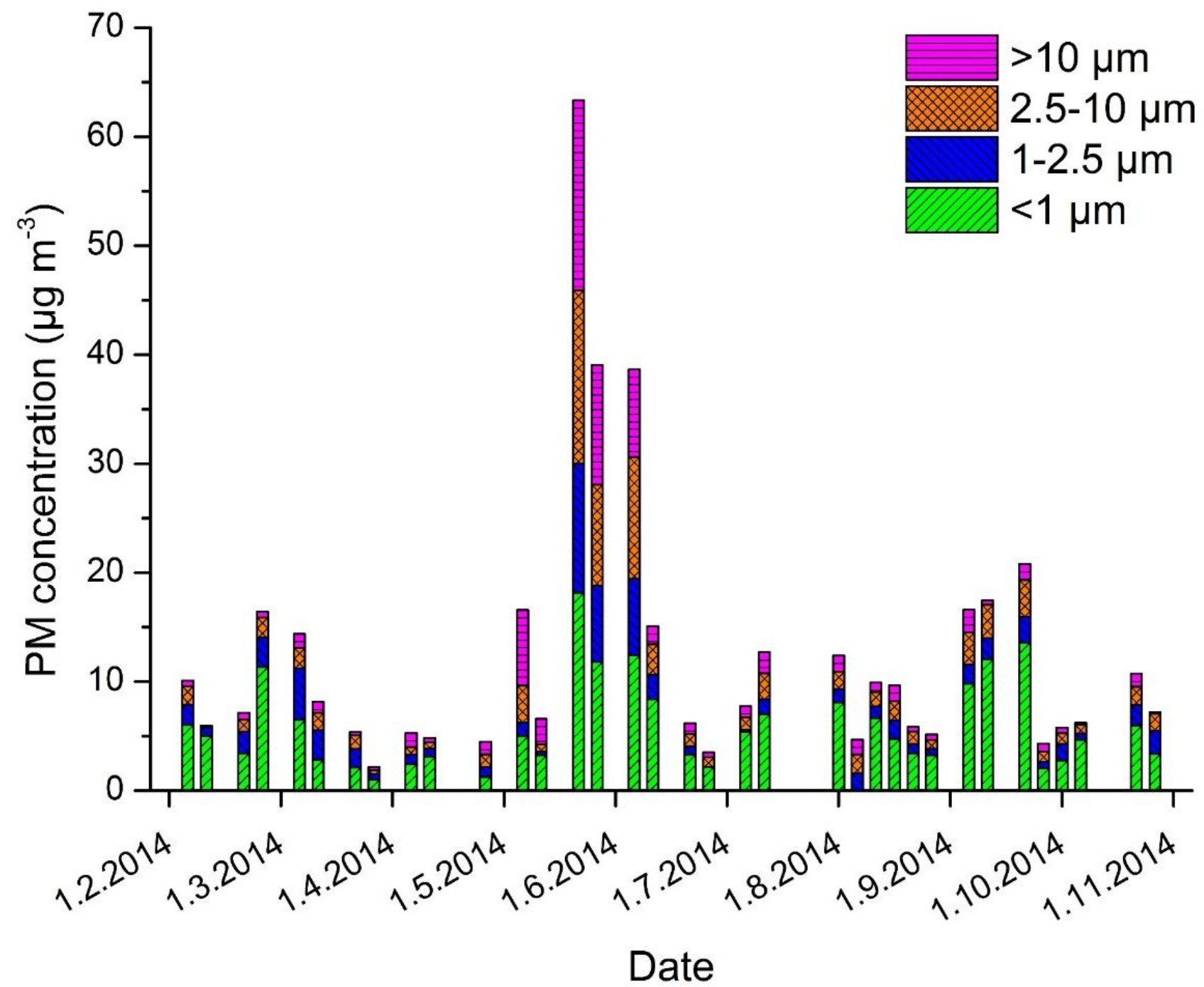

Figure S3. Particulate matter (PM) concentration over the sampling period in different particle size fractions. 


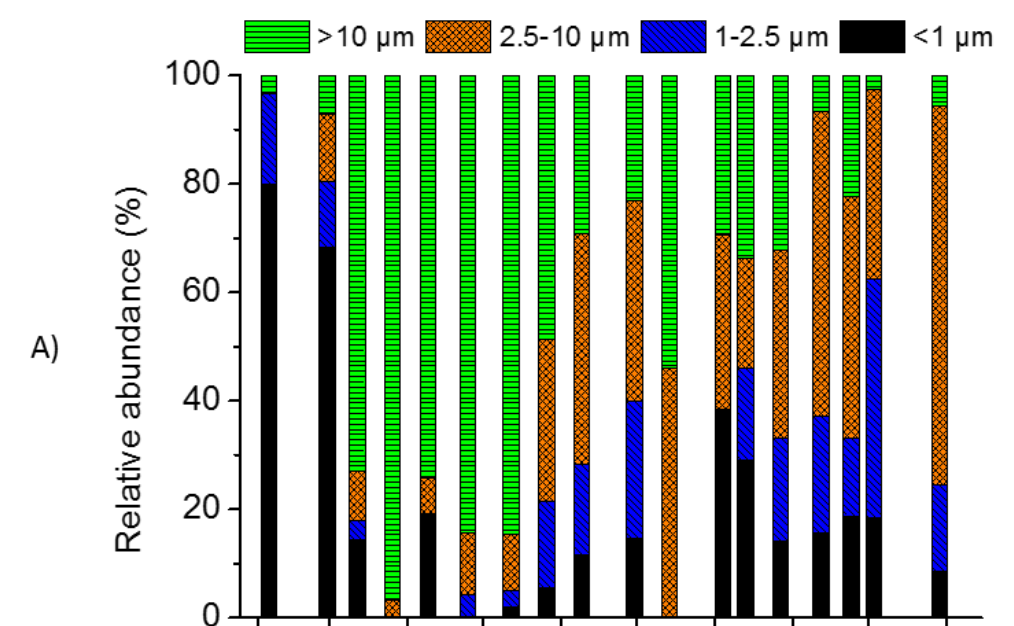

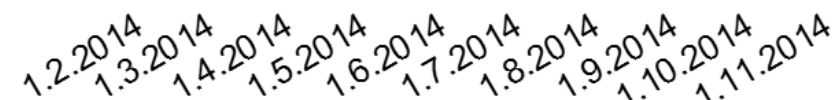
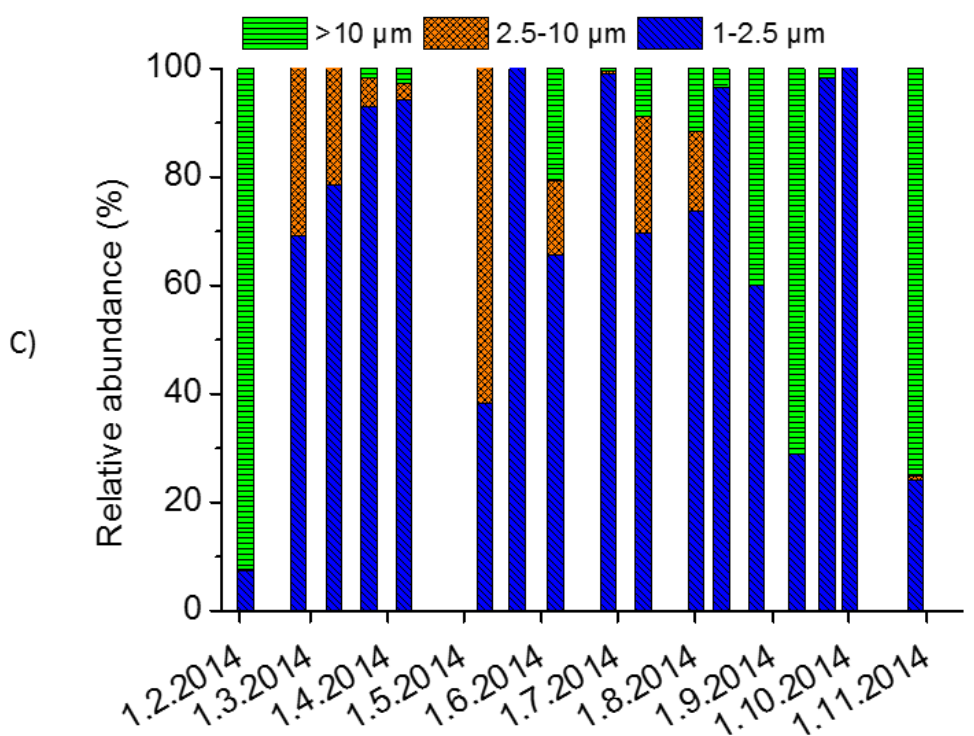
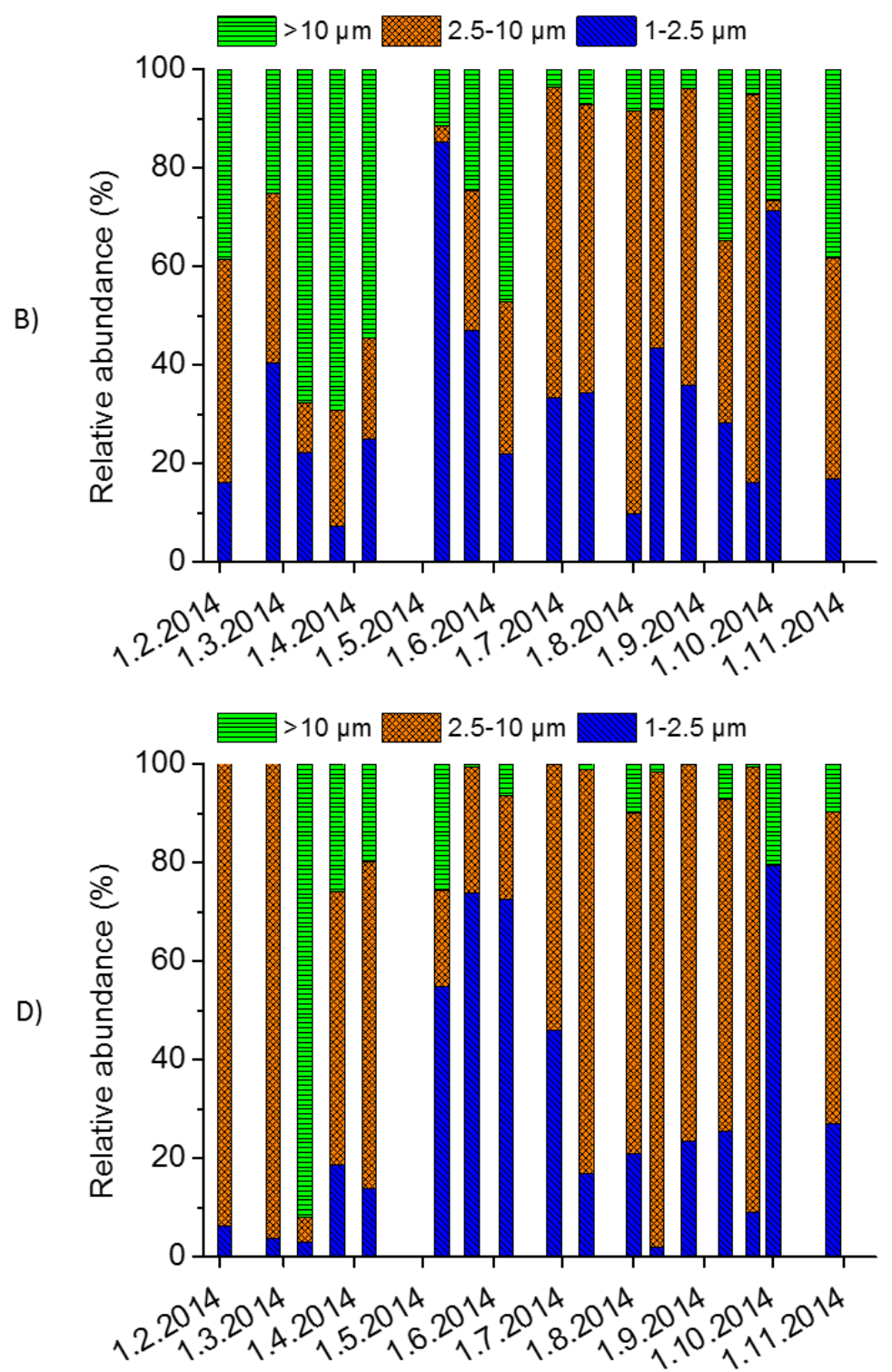

Figure S4. Relative abundance of a) free amino acids b) bacteria c) Pseudomonas and d) fungi in different particle size fractions. 

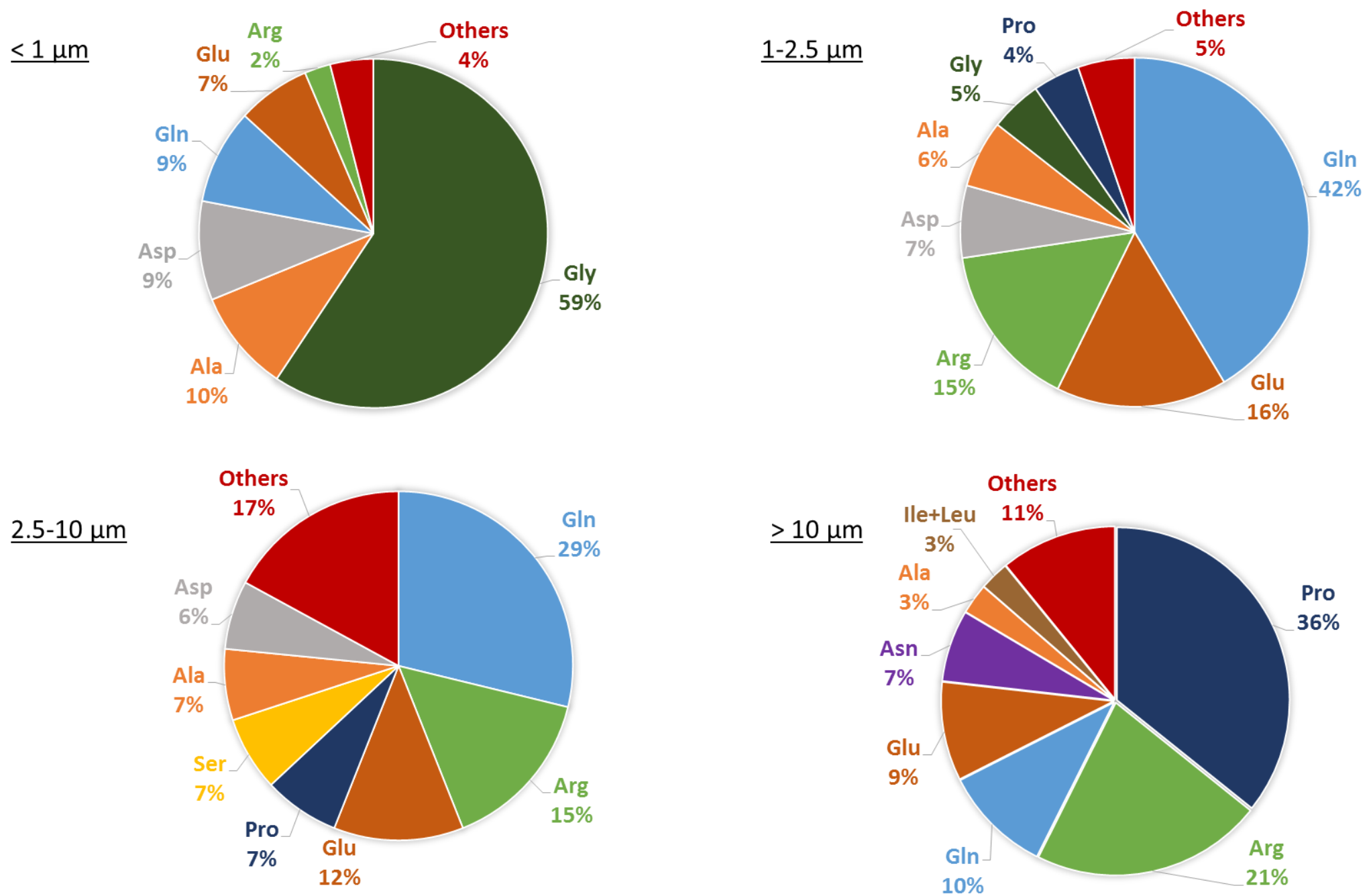

Figure S5. Amino acid relative concentration distribution in each size fraction (calculated as percentage of the cumulative amount). One pollen season sampling date was excluded from the calculations due to the dominance of proline and arginine. 


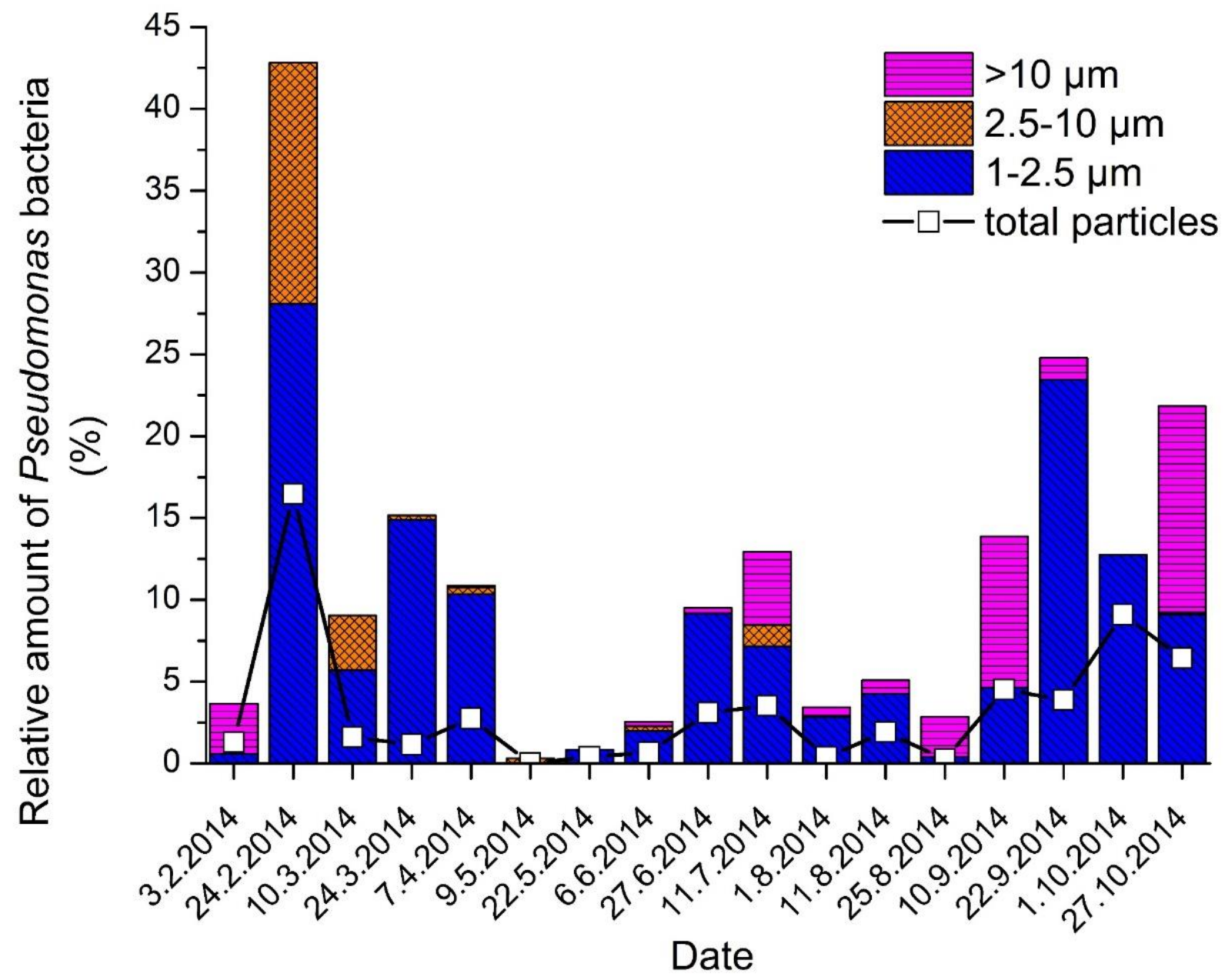

Figure S6. Relative amount of bacteria belonging to genus Pseudomonas compared against all the bacteria detected in different size fractions and in total particles. 


\section{S4. Results from correlation analysis.}

As discussed in the article, our meteorological variables correlation results are showing long-term effects of bioaerosols due to the time resolution of sampling. Note, that in case of correlation between individual amino acids, the results may not be representative, despite statistical significance. This is due to the fact that some amino acids were present in the same limited number of samples (detection frequency, Table S6). Thus, herein we will focus mainly on the total FAA and microorganism correlation results.

A general trend observed in the correlation results in different size fractions were the positive correlation between FAA and microorganisms with soil and air temperature (Figure S7 and Figure S8). In the case of FAA, air temperature showed positive correlation in all the size fractions, and soil temperature showed statistically significant correlation in all the size fractions except in the largest size fraction $(>10 \mu \mathrm{m})$. Fungal DNA concentration correlated positively with air and soil temperature in all the size fractions, whereas bacterial DNA concentration did not correlate with these parameters in the largest size fraction $(>10 \mu \mathrm{m})$. Oppositely, Pseudomonas showed positive correlation between soil temperature only in the largest size fraction $(>10 \mu \mathrm{m})$, but not in the smallest size fractions $(1-2.5 \mu \mathrm{m}$ and 2.5-10 $\mu \mathrm{m})$. All of the before mentioned meteorological variables are closely related to local biological activity and seasonality. High concentration levels of FAA and microorganisms were generally observed in spring-autumn; seasons which are typically related to increased biological activity.

Negative correlation between microorganisms' concentrations with wind speed in the small size fractions (particles below $10 \mu \mathrm{m}$ ) was observed. Microorganisms may be removed from plant surfaces by higher wind speed, however, at the same time dilution and/or deposition may lower the concentration levels in the nearsurface atmosphere. ${ }^{5}$ Wind speed was higher during cold months and lower during warm months, opposite to trend in microorganism abundances observed in this study. By our opinion, low time resolution of sampling is responsible for some correlation, which is a clear drawback of our study. 


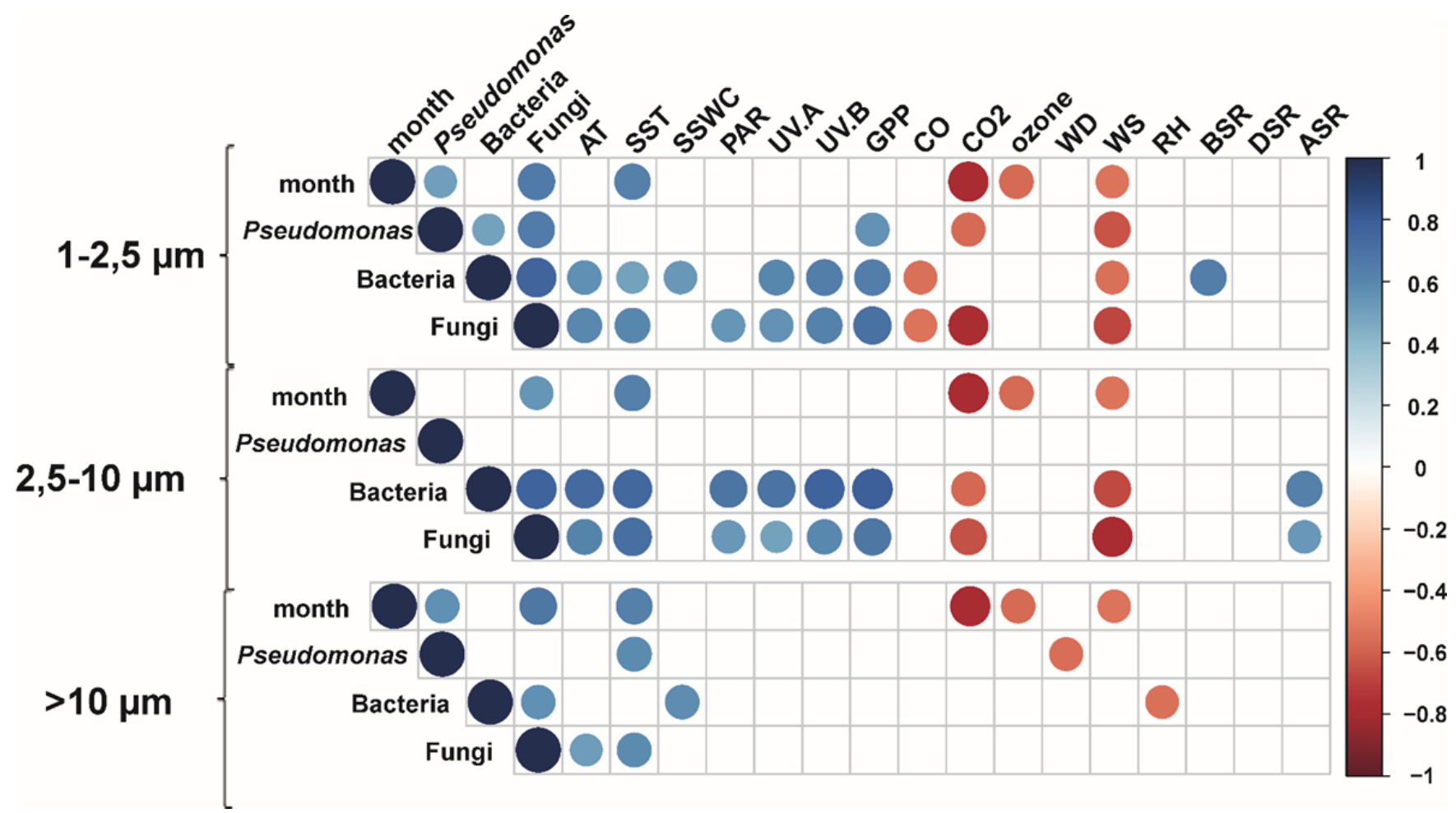

Figure S7. Illustration of correlation diagram presenting Spearman correlations between microorganisms with meteorological variables. The colour scale indicates negative/positive correlation and the size of the ball statistical significance level $(\mathrm{p}<0.05)$. Abbreviations: AT-air temperature; SST-soil surface temperature; SSWC-soil surface water content; WS-wind speed; WD-wind direction; GPP-gross primary production; CO; $\mathrm{CO}$; ozone concentration; PAR-photosynthetically active radiation; UV-A and UV-B radiation; RH-relative humidity; BSR-rainfall $72 \mathrm{~h}$ before sampling; DSR-rainfall during sampling; ASR-rainfall $168 \mathrm{~h}$ after sampling. 


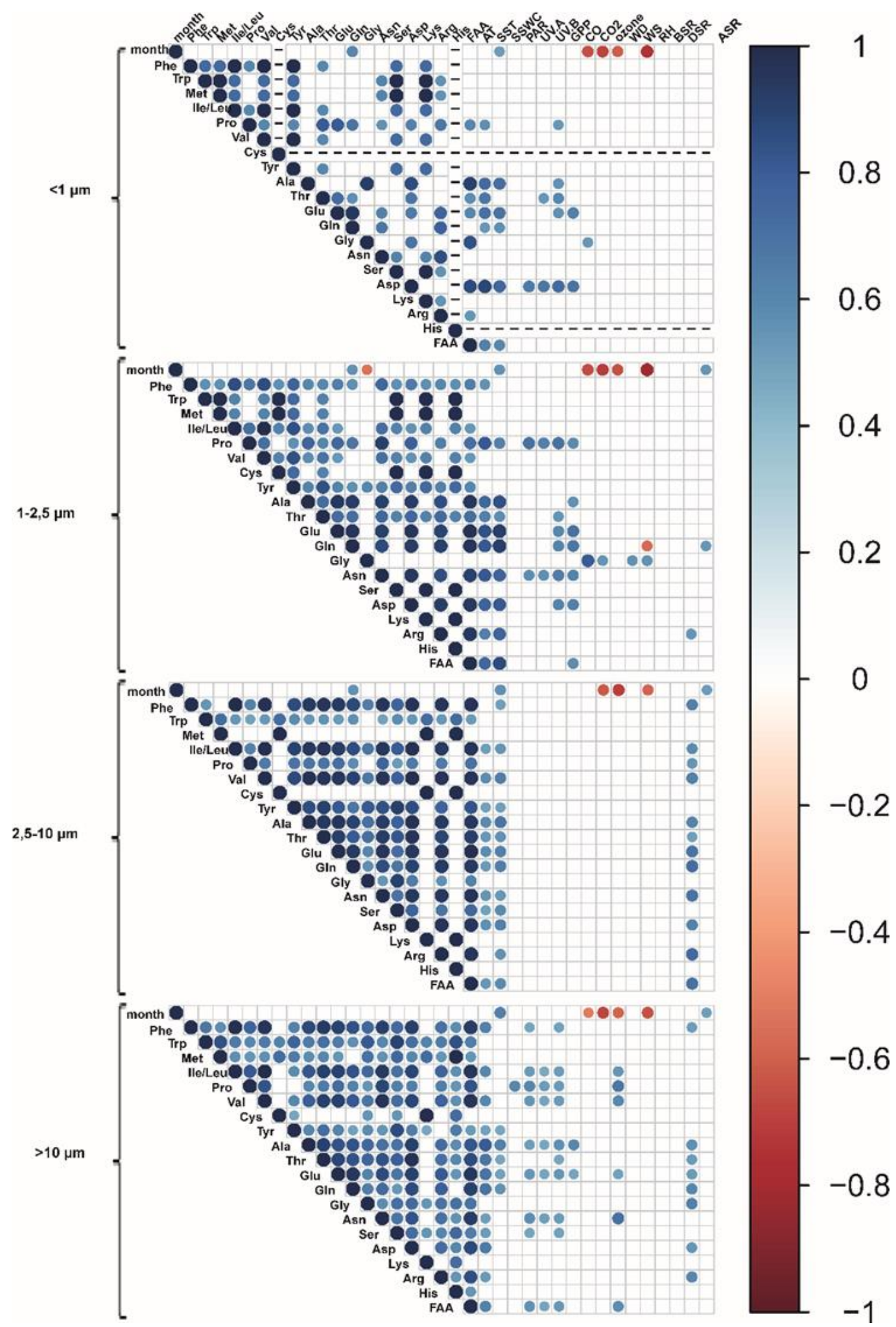

Figure S8. Illustration of correlation diagram presenting Spearman correlations between free amino acids with meteorological variables. The colour scale indicates negative/positive correlation and the size of the ball statistical significance level $(\mathrm{p}<0.05)$. Abbreviations of meteorological parameters are the same as in Figure S7. 


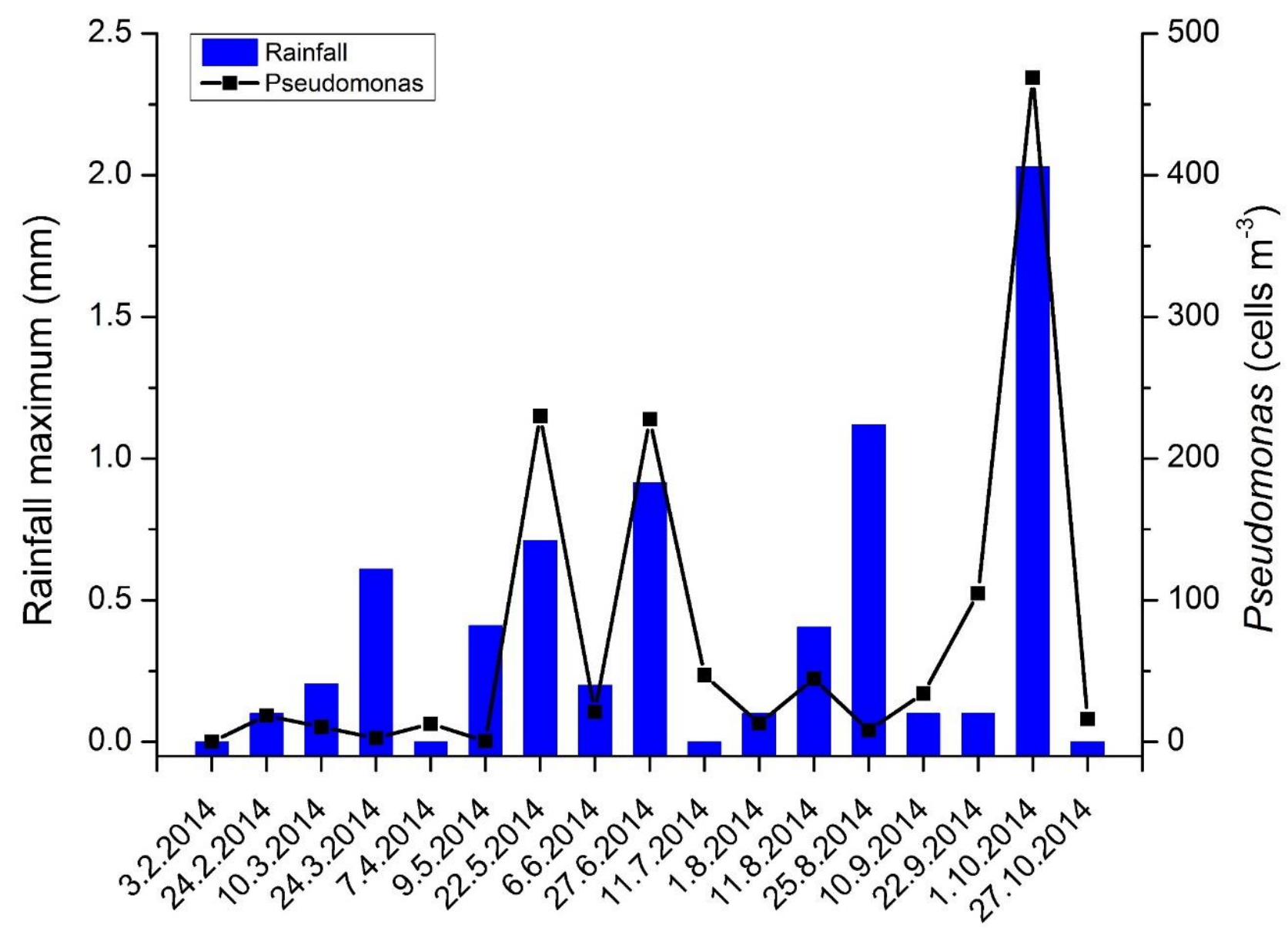

Figure S9. The pattern of Pseudomonas concentration in the size fraction 1-2.5 $\mu \mathrm{m}$ and maximum amount of rainfall recorded on a single 30 min event within $72 \mathrm{~h}$ before sampling. 
S5. Estimation of biomass contribution to particulate matter in aerosols.

\section{Contribution of FAA and DNA to PM}

The relative amount of FAA mass to PM mass in total particles over the year was on average $0.33 \pm 0.45 \%$ (range 0.02-1.92\%). The FAA concentration correlated positively with PM concentration in total particles $(\mathrm{R}=0.54, \mathrm{p}<0.05)$. In different size fractions the percentage of FAA/PM $(\mathrm{w} / \mathrm{w}-\%)$ was: $0.07 \pm 0.08 \%(<1 \mu \mathrm{m})$, $0.36 \pm 0.48 \%(1-2.5 \mu \mathrm{m}), 0.50 \pm 0.62 \%(2.5-10 \mu \mathrm{m})$ and $0.83 \pm 0.98 \%(>10 \mu \mathrm{m})$. The highest portion of FAA/PM (w/w-\%) was observed in the size fraction $>10 \mu \mathrm{m}$ during the pollen season peak in May, when the FAA accounted for $3.32 \%$ of the PM. In general, the relative amount of FAA to PM was higher in the large sized particles $(>2.5 \mu \mathrm{m})$ than in the small sized particles $(<2.5 \mu \mathrm{m})$. Statistically significant correlation was observed between the FAA concentration with PM concentration in all of the size fractions except in the size fraction $1-2.5 \mu \mathrm{m}(\mathrm{R}=0.53, \mathrm{p}<0.05$ for $<1 \mu \mathrm{m} ; \mathrm{R}=0.18, \mathrm{p}=0.53$ for $1-2.5 \mu \mathrm{m} ; \mathrm{R}=0.54, \mathrm{p}<0.05$ for $2.5-10 \mu \mathrm{m}$ and $\mathrm{R}=0.77, \mathrm{p}<0.001$ for $>10 \mu \mathrm{m})$.

The relative amount of DNA mass to PM mass in total particles over the year was on average $0.15 \pm 0.16 \%$ (range 0.01-0.47\%). No statistically significant correlation was observed between DNA concentration with PM concentration in total particles. On average the relative amount of DNA/PM (w/w- $\%)$ in different size fractions was: $0.30 \pm 0.39 \%(1-2.5 \mu \mathrm{m}), 0.10 \pm 0.13 \%(2.5-10 \mu \mathrm{m})$ and $0.22 \pm 0.47 \%(>10 \mu \mathrm{m})$. The relative amount of DNA/PM (w/w-\%) was highest in total particles in late spring $(0.42 \%)$, late summer $(0.44 \%)$ and autumn $(0.47 \%)$. Opposite to the trend observed with FAA, DNA showed bimodal relative amount distribution, namely being highest in the size fractions $1-2.5 \mu \mathrm{m}$ and $>10 \mu \mathrm{m}$ and lowest in the size fraction $2.5-10 \mu \mathrm{m}$. DNA concentration and PM concentration did not correlate with statistically significance in any of the size fractions.

\section{Estimation of biomass in aerosols}

Amino acids have been previously used as an indicator for biomass in aerosols by using an estimation that on average $\sim 10 \%$ of biomass is composed of proteins. ${ }^{6,7}$ In order to estimate the relative abundance of biomass in aerosols, we first converted FAA data into the form of combined amino acids (i.e. to proteins and peptides). FAA concentrations were multiplied by a factor of four based on previous studies conducted at rural and semiurban sites. ${ }^{8-10}$ This correction factor is only a rough estimate and can be lower or higher depending on the season and size fraction. ${ }^{10}$ Nevertheless, we assume it is suitable for our approximation purpose. After the conversion of FAA to proteins, we used the $\sim 10 \%$ estimate to obtain the relative amount of biomass in aerosols. ${ }^{6}$ This approximation leads to the following proportion of biomass/PM (w/w-\%) in different size fractions: $3 \pm 3 \%(<1 \mu \mathrm{m}), 14 \pm 19 \%(1-2.5 \mu \mathrm{m}), 20 \pm 25 \%(2.5-10 \mu \mathrm{m})$ and $33 \pm 39 \%(>10 \mu \mathrm{m})$. In total particles, the corresponding biomass/PM (w/w- $\%$ ) was over the year $13 \pm 20 \%$, ranging from $1 \%$ to $77 \%$. These results seem reasonable, if taking into account the general estimation that on average $\sim 30 \%$ of PM mass is composed of bioaerosols. ${ }^{11}$ However, the drawback of our estimation method is that the ratio of FAA to proteins can vary seasonally whereas we assume it to be constant. ${ }^{10}$ Further, the relative amount of proteins in biomass varies greatly, ${ }^{6,7}$ yet we assume it to be constant. Thus, the uncertainty here can be significant (see also Hock et al. and Schneider et al.). ${ }^{6,7}$ However, our results indicate that the fraction of bioaerosols can be substantial during the local pollen season as suggested by Manninen et al. ${ }^{12}$ Based on our estimation, the relative amount of biomass in total particles would be $\sim 77 \%$, comparable to the $65 \%$ proposed by Manninen et al. ${ }^{12}$

Another option to estimate the relative amount of biomass in aerosols would be to use the information obtained from the total DNA amount. In general, DNA amount is known to correlate with the microbial biomass. ${ }^{13}$ However, estimating the proportion of DNA in biomass is challenging especially in case of aerosol samples due to the varying cell and genome sizes of putative PBAP-organisms, such as bacteria, fungi/fungal spores and plant cells/pollen. ${ }^{13,14}$ If assuming that $4 \%$ of biomass is composed of DNA, ${ }^{15}$ the following ratio of biomass/PM (w/w-\%) would be in different size fractions: $8 \pm 10 \%(1-2.5 \mu \mathrm{m}), 3 \pm 10 \%(2.5-10 \mu \mathrm{m})$ and $6 \pm 12 \%$ $(>10 \mu \mathrm{m})$. In total particles, the corresponding estimation method gave biomass/PM (w/w- $\%)$ ratio of $4 \pm 4 \%$ (range 0.2-12\%). This DNA conversion to biomass gave even up to 6-fold smaller biomass/PM-ratio, when compared to the estimation derived from using FAA to estimate the biomass amount in aerosols. Even though the sampling times differed between DNA and FAA samples (Table S1), it is unlikely that this would result in 
such a significant difference in biomass proportion on average, but is more likely to occur due to the variance of cell sizes of PBABs.

Collectively, these estimation methods presented here are prone to error, yet they give us a general estimate of the amount and seasonal variations of biomass in aerosols at the boreal forest site. By using the information obtained from both estimation methods, we obtained the following seasonal contribution of biomass in aerosols. The proportion of biomass is likely negligible during winter ( 1\% in total particles), whereas during spring and local pollen season the portion can be substantial ( 11-77\% in total particles). In addition, in late summer and autumn, the portion of biomass can be occasionally $~ 10 \%$ in total particles. 
1. Magnusson, B., Handbook for calculation of measurement uncertainty in environmental laboratories. In 2003.

2. $\quad$ Fierer, N.; Jackson, J. A.; Vilgalys, R.; Jackson, R. B., Assessment of soil microbial community structure by use of taxon-specific quantitative PCR assays. Applied and environmental microbiology 2005, 71, (7), 4117-4120.

3. Purohit, H. J.; Raje, D. V.; Kapley, A., Identification of signature and primers specific to genus Pseudomonas using mismatched patterns of 16S rDNA sequences. BMC bioinformatics 2003, 4, (1), 19.

4. Vainio, E. J.; Hantula, J., Direct analysis of wood-inhabiting fungi using denaturing gradient gel electrophoresis of amplified ribosomal DNA. Mycological research 2000, 104, (8), 927-936.

5. Jones, A. M.; Harrison, R. M., The effects of meteorological factors on atmospheric bioaerosol concentrations - a review. Science of The Total Environment 2004, 326, (1-3), 151-180.

6. Hock, N.; Schneider, J.; Borrmann, S.; Römpp, A.; Moortgat, G.; Franze, T.; Schauer, C.; Pöschl, U.; Plass-Dülmer, C.; Berresheim, H., Rural continental aerosol properties and processes observed during the Hohenpeissenberg Aerosol Characterization Experiment (HAZE2002). Atmospheric Chemistry and Physics 2008, 8, (3), 603-623.

$7 . \quad$ Schneider, J.; Freutel, F.; Zorn, S.; Chen, Q.; Farmer, D.; Jimenez, J.; Martin, S.; Artaxo, P.; Wiedensohler, A.; Borrmann, S., Mass-spectrometric identification of primary biological particle markers and application to pristine submicron aerosol measurements in Amazonia. Atmospheric Chemistry and Physics 2011, 11, (22), 11415-11429.

8. $\quad$ Samy, S.; Robinson, J.; Rumsey, I. C.; Walker, J. T.; Hays, M. D., Speciation and trends of organic nitrogen in southeastern US fine particulate matter (PM2. 5). Journal of Geophysical Research: Atmospheres 2013, 118, (4), 1996-2006.

9. Zhang, Q.; Anastasio, C., Free and combined amino compounds in atmospheric fine particles (PM 2.5) and fog waters from Northern California. Atmospheric Environment 2003, 37, (16), 2247-2258.

10. Matos, J. T.; Duarte, R. M.; Duarte, A. C., Challenges in the identification and characterization of free amino acids and proteinaceous compounds in atmospheric aerosols: A critical review. TrAC Trends in Analytical Chemistry 2016, 75, 97-107.

11. Després, V. R.; Huffman, J. A.; Burrows, S. M.; Hoose, C.; Safatov, A. S.; Buryak, G.; FröhlichNowoisky, J.; Elbert, W.; Andreae, M. O.; Pöschl, U., Primary biological aerosol particles in the atmosphere: a review. Tellus B 2012, 64 .

12. Manninen, H. E.; Bäck, J.; Sihto-Nissilä, S.-L.; Huffman, J. A.; Pessi, A.-M.; Hiltunen, V.; Aalto, P. P.; Hidalgo Fernández, P. J.; Hari, P.; Saarto, A., Patterns in airborne pollen and other primary biological aerosol particles (PBAP), and their contribution to aerosol mass and number in a boreal forest. Boreal Environment Research 2014, 19, 383-405.

13. Taylor, J.; Wilson, B.; Mills, M. S.; Burns, R. G., Comparison of microbial numbers and enzymatic activities in surface soils and subsoils using various techniques. Soil Biology and Biochemistry 2002, 34, (3), 387-401.

14. Leckie, S. E.; Prescott, C. E.; Grayston, S. J.; Neufeld, J. D.; Mohn, W. W., Comparison of chloroform fumigation-extraction, phospholipid fatty acid, and DNA methods to determine microbial biomass in forest humus. Soil Biology and Biochemistry 2004, 36, (3), 529-532.

15. Marstorp, H.; Guan, X.; Gong, P., Relationship between dsDNA, chloroform labile C and ergosterol in soils of different organic matter contents and pH. Soil Biology and Biochemistry 2000, 32, (6), 879-882. 